\title{
Correction to: Poly(lactic acid)/poly(lactic-co-glycolic acid)-based microparticles: an overview
}

\author{
Paolo Blasi ${ }^{1}$ (1)
}

Published online: 25 July 2019

(c) The Author(s) 2019

\section{Correction to: Journal of Pharmaceutical Investigation (2019) 49:337-346 \\ https://doi.org/10.1007/s40005-019-00453-z}

The article Poly(lactic acid)/poly(lactic-co-glycolic acid)based microparticles: an overview, written by Paolo Blasi, was originally published electronically on the publisher's internet portal (currently SpringerLink) on 11 June 2019 without open access.

With the authors' decision to opt for Open Choice the copyright of the article changed on 19 July 2019 to (C) The Author(s) 2019 and the article is forthwith distributed under the terms of the Creative Commons Attribution 4.0 International License (http://creativecommons.org/licenses/by/4.0/), which permits use, duplication, adaptation, distribution and reproduction in any medium or format, as long as you give appropriate credit to the original author(s) and the source, provide a link to the Creative Commons license and indicate if changes were made.

Open Access This article is distributed under the terms of the Creative Commons Attribution 4.0 International License (http://creativeco mmons.org/licenses/by/4.0/), which permits unrestricted use, distribution, and reproduction in any medium, provided you give appropriate credit to the original author(s) and the source, provide a link to the Creative Commons license, and indicate if changes were made.

Publisher's Note Springer Nature remains neutral with regard to jurisdictional claims in published maps and institutional affiliations.
The original article can be found online at https://doi.org/10.1007/ s40005-019-00453-z.

\section{Paolo Blasi}

paolo.blasi@unicam.it

1 School of Pharmacy, University of Camerino, via Gentile III da Varano, 62032 Camerino, Italy 